\title{
Gymnastická hra jako podnět k modernizaci výuky gymnastiky ve školní tělesné výchově
}

\section{Gymnastic game as an incentive to modernize teaching of gymnastics in physical education at schools}

\author{
Jitka Vorálková, Viléma Novotná, Iveta Šimůnková
}

Fakulta tělesné výchovy a sportu, Univerzita Karlova v Praze

\begin{abstract}
Abstrakt
$V$ předmètu tělesná výchova je na všech stupních škol zařazena gymnastika. Gymnastické dovednosti osvojované $v$ rámci gymnastických her se mohou specifickým způsobem podílet na rozvijeni jednotlivých kompetenci žáků, podporovat úroveň pohybové gramotnosti, přispivat k rozvoji vybraných složek tělesné zdatnosti a podněcovat pohybovou tvořivost. V současnosti však gymnastika jako cvičení na nár̆adi není dostatečně zařazována do školních programů tělesné výchovy. Důvodem je neuspokojivý rozsah připravy učitelů, tradični metody výuky a zastaralé nebo nulové vybaveni školnich tělocvičen. Jednou z možností změny $v$ př́stupu $k$ výuce je využití gymnastických her, nově konstruovaných typư nářadí a programů vytvářených na základě koncepce vzdèlávacího programu Gymnastika pro všechny (GFA). Gymnastické hry spolu s modernimi pomi̊ckami jsou pro nácvik specifických dovedností pro žáky atraktivní a inspirativní. Zvyšují bezpečnost nácviku a rozšiřuji množství impulsủ pro podněcováni tvořivosti. Předpokládáme, že modernizace výuky gymnastiky prostřednictvím gymnastických her bude rozvíjet kompetence žáka, zvýši úroveň pohybové gramotnosti, rozšiři počet osvojených dovedností a stane se důležitou motivaci k celoživotni pohybové aktivitě vedouci ke zdravému životnimu stylu.
\end{abstract}

\section{Abstract}

Gymnastics is included in the physical education at all school levels. Gymnastic skills learned in the gymnastic games may specifically contribute to the development of pupils'skills, promote physical literacy level, contribute to the development of selected components of physical fitness and stimulate movement creativity. Nowadays the concept of gymnastics as an apparatus exercises, is not enough included in school physical education programs.

The reasons are: unsatisfactory range of teachers preparation, traditional teaching methods or no equipment and apparatus at school gyms. One possible significant changes in the approach of teaching is to use gymnastic games and newly designed types of equipment and programs created under the concept of curriculum Gymnastics for all (GFA). Gymnastic games along with modern apparatus are attractive, appealing and inspiring for specific movement skills. They improve safety of training, and expand the range of creativity. We assume that the modernization and inovation of teaching gymnastics through gymnastic games will develop pupils' competence,increase the level of physical literacy, increase the number of skills and becomes an important motivation for lifelong physical activity leading to a healthy lifestyle.

Klíčová slova: Kompetence, pohybová gramotnost, gymnastické dovednosti, tvořivost, inovace, hra

Keywords: Competence, physical literacy, gymnastic skills, creativity, innovation, game

Př́spěvek je součástí projektu PRVOUK P 15 a P 39, Univerzity Karlovy v Praze, FTVS. 


\section{ÚVOD}

V předmětu tělesná výchova je na všech stupních škol zařazena gymnastika. Původní osnovy pro výuku uváděly jako závazné učivo jednotlivé gymnastické dovednosti. V současnosti je v Rámcových vzdělávacích programech (RVP) uvedena gymnastika ve formě oblastí souborů gymnastických cvičení nebo programů (např. cvičení průpravná, koordinační, kondiční, akrobatická, s náčiním, na nářadí a tance). Další doporučené okruhy výuky jsou formulovány ještě obecněji (např. vyjádření melodie a rytmu pohybem, pohybová tvořivost). $\mathrm{Na}$ všech stupních škol jsou ale vždy uvedeny v rámci obsahu učiva Činnosti ovlivňující úroveň pohybových dovedností ,pohybové hry“ $s$ různým zaměřením.

Jednou z inovací školské reformy je zavedení klíčových kompetencí a jejich osvojování ve vzdělávacím procesu, které mají žákům usnadnit plnohodnotný život ve 21. století (Belz \& Siegrist, 2001). Gymnastika a gymnastické dovednosti osvojované v rámci gymnastických her se mohou specifickým způsobem podílet na ovlivňování jednotlivých kompetencí, podporovat úroveň pohybové gramotnosti, současně přispívat k rozvoji vybraných složek tělesné zdatnosti a podněcovat pohybovou tvořivost.

Jedna z částí disertační práce zabývající se procesem přípravy učitelů v oblasti gymnastiky je zaměřena na nové pojetí výuky gymnastiky a její začlenění v předmětu tělesná výchova. Z výsledků různých šetření (např. Sigmund et al., 2009; Bučar, 2010; Živčić, 2011; Solan, 2007) je možno konstatovat negativní skutečnost, že gymnastika pojatá jako cvičení na nářadí není často v potřebném rozsahu zařazována do školních programů tělesné výchovy a že patř́ mezi málo oblíbené a vyhledávané činnosti. Důvodů této nepříznivé situace je několik. Za prvé to je nedostatečná připravenost učitelů na výuku daná stále se zmenšujícím rozsahem teoreticko-praktické př́pravy učitelů na fakultách a mnohdy i „tradičními“ metodami výuky, zejména cvičení s využitím „tradičního typu“ nářadí. Dalším neduhem je zastaralé, někde téměř nulové vybavení tělocvičen pro školní tělesnou výchovu. Uvedené okolnosti vyvolávají potřebu výrazné změny $\mathrm{v}$ př́stupu $\mathrm{k}$ výuce gymnastiky. Jednou z možností oživení je využití gymnastických her, nově konstruovaných typů nářadí a programů vytvářených na základě koncepce vzdělávacího programu Mezinárodní gymnastické federace (FIG), realizované prostřednictvím komise Gymnastics For All (Gymnastika pro všechny). Cílem cvičení je myšlenka, že není důležitý výkon, ale že gymnastika je vhodná pro každého, bez ohledu na věk, pohlaví a výkonnost.

\section{METODIKA}

Cílem př́spěvku je na základě analýzy, výběru a komparací teoretických východisek z kurikulárních dokumentů RVP, procesu př́pravy učitelů, významů hry pro proces vzdělávání, využití koncepce Gymnastics for all (GFA) a možností ovlivňování kompetencí žáků prostřednictvím gymnastických her navrhnout inovaci programu výuky gymnastiky, a to cvičení na netradičním nářadí. Představit učitelům, jak přiblíží žákům a studentům takový typ gymnastické pohybové aktivity, která by podporovala pohybovou gramotnost a pohybovou tvořivost, kultivovala pohybový projev, přinášela nové dovednosti přenositelné do dalších pohybových aktivit, přiměřeně ovlivňovala úroveň tělesné zdatnosti a motivovala k dlouhodobé potřebě pohybu.

\section{VÝSLEDKY A DISKUSE}

\section{Kurikulární dokumenty}

Obor Tělesná výchova (TV) tvoří společně s oborem Výchova ke zdraví vzdělávací oblast Člověk a zdraví. Obsahuje charakteristiku vzdělávací oblasti, její cílové zaměření a obsah. Předmět tělesná výchova je součástí povinného vzdělávání na všech stupních vzdělávání - základním (ZŠ), středním (SŠ) i vysokoškolském (VŠ). Tělesná výchova je $\mathrm{v}$ učebních plánech ZŠ a SŠ zařazována v rozsahu dvou vyučovacích hodin týdně, téměř není využívána pravomoc ředitelů umožňující jeho zvýšení. Evropský doporučovaný standard je vyšší, např. Francie a Rakousko mají počet hodin TV za školní rok 102-108, což jsou 3 hodiny týdně (Eacea, 2013).

Podle Balady (2007) je v RVP pro základní vzdělávání učivo gymnastiky vymezeno pro 1. stupeň: Pohybové hry - s různým zaměřením; netradiční pohybové hry a aktivity; využití hraček a netradičního náčiní při cvičení; pohybová tvořivost; Rytmické a kondiční formy cvičení pro děti - kondiční cvičení s hudbou nebo rytmickým doprovodem, základy estetického pohybu, vyjádření melodie a rytmu pohybem, jednoduché tance; Základy gymnastiky - průpravná cvičení; jednoduchá akrobatická cvičení; cvičení s náčiním a na nářadí. Pro 2. stupeň: Pohybové hry - s různým zaměřením; netradiční pohybové hry a aktivity; Gymnastika - akrobacie, přeskoky, cvičení s náčiním a na nářadí; Estetické a kondiční formy cvičeni s hudbou a rytmickým doprovodem - základy 
rytmické gymnastiky, cvičení s náčiním; kondiční formy cvičení pro daný věk žáků; tance.

V Rámcovém vzdělávacím programu pro gymnázia je obsah učiva gymnastiky vymezen:

Průpravná, kondiční, koordinační, tvořivá, estetická a jinak zaměřená cvičení; Pohybové hry různého zaměřeni; Gymnastika - akrobacie; přseskoky a cvičení na nářadí; cvičení s náčiním;

Kondični a estetické formy cvičeni s hudbou a rytmickým doprovodem (určeno především děvčatům alespoň dvě formy cvičení podle podmínek a zájmu žákyň, př́padně žáků).

Každá škola má právo zpracovat svůj konkrétní školní vzdělávací program (ŠVP) přizpůsobený podmínkám a potřebám školy. Tento ŠVP si vytvárí podle zásad stanovených $\mathrm{v}$ př́íslušném RVP. Bylo by zajímavé porovnat obsah ŠVP na stejném stupni na různých školách, ale tyto materiály nejsou v dostatečném počtu dostupné. Zařazování gymnastiky do výuky záleží na zaměření učitele a jeho vztahu ke gymnastickým aktivitám.

Jednou z inovací školské reformy je zavedení klíčových kompetencí a jejich osvojování ve vzdělávacím procesu. V etapě základního vzdělávání jsou za klíčové kompetence žáků považovány: kompetence k učení, kompetence $\mathrm{k}$ řešení problémů, kompetence komunikativní, kompetence sociální a personální, kompetence občanské a kompetence pracovní. Zatímco v učebních osnovách před školskou reformou je učivo TV děleno na základní, rozšiřující či výběrové a jsou odlišena cvičení pouze pro chlapce nebo dívky, v rámcových vzdělávacích programech se již tato diference nevyskytuje.

\section{Př́prava učiteli̊ a praxe školni TV}

V nově strukturovaných programech učitelství se na většině fakult připravujících učitele snižuje rozsah praktické didaktické výuky jednotlivých ,sportovních“ předmětů. Např́íklad na UK FTVS je výrazně změněn rozsah a v důsledku toho i obsah předmětů gymnastiky podílejících se na vytváření profesních kompetencí učitele TV. Nižší hodinové dotace vedou ke značné diferenci jak v Evropě, tak i v našich institucích připravujících budoucí učitele tělesné výchovy (odlišné názvy, obsah i rozsah prímých vyučovacích lekcí, počty kreditů (Rychtecký et al., 2008).

Volnost ve výběru učiva dává učitelům možnost se v rámci tvorby školních programů některým tematickým celkům vyhnout. Například Chrudimský (2011) uvádí výčet argumentů, které jsou základem neoblíbenosti gymnastiky. Patři mezi ně právě problémy při organizaci cvičenců - zvláště používání tradičních stylů výuky na nářadí (jeden žák cvičí, ostatní sedí nebo sledují). Dále také nedostatečné kompetence učitele (specifické znalosti a dovednosti) a v neposlední řadě finanční, prostorová a materiálně technická náročnost výuky. Negativní odezvy na cvičení na nářadí i ze strany žáků uvádí Sigmund a kol. (2009). Domnívají se, že k zatraktivnění i méně preferovanému obsahu školní TV může přispět vyšší pestrost nabízených aktivit, střídání intenzivnějších částí vyučovacích jednotek TV s méně intenzivními částmi a především herní forma rutinně prováděných cvičení.

\section{Hry a jejich využití}

Průcha, Walterová a Mareš (1995) definují hru jako formu činnosti, která se liší od práce i od učení. Hra má řadu aspektů: aspekt poznávací, procvičovací, emocionální, pohybový, motivační, tvořivostní, fantazijní, sociální, rekreační, diagnostický, terapeutický. Zahrnuje činnosti jednotlivce, dvojice, malé skupiny i velké skupiny. Existují hry, k jejichž provozování jsou nutné speciální pomůcky (hračky, herní pomůcky, sportovní náčiní, nástroje, př́stroje). Většina her má podobu sociální interakce s jasně formulovanými pravidly. Ve hře je velká pozornost věnována jejímu průběhu, zaměřenému na spolupráci nebo na soutěžení. Účelem her není jen zábava, ale v oblasti vzdělávání představuje zajímavou výukovou metodu. Hru jako výchovný prostředek zdůrazňovali v historii např́klad Rousseau a Locke, v současnosti Němec (2004), Neuman (2007) a další.

Za důležité považujeme připomenout J. A. Komenského, podle kterého bylo cílem her cvičení těla i ducha. Hry měly podporovat sílu a mrštnost těla, veselost mysli, smysl pro řád, měly bystřit lidský rozum a upevňovat charakter. Ve své pedagogické praxi i v teoretických úvahách zdůrazňoval, že prostřednictvím hry si dítě osvojí potřebné znalosti snáze a lépe, než zastrašováním a př́lišnou přísností, a proto se škola má státi hrou. Stanovil sedm podmínek, dokládajících, že „hra jest hrou“. Na první místo stavěl pohyb. Druhým rysem hry byla naprostá volnost a svoboda rozhodnutí účastnit se hry, třetím společenský charakter hry, čtvrtým soutěžení, pátým řád a pravidla, šestým snadnost a sedmým pak její časová omezenost (Olivová, 1979). 


\section{Pojem hra a hrát si}

Perič (2004) poukazuje na nezbytnost odlišení významu pojmů hra a hrát si. Potřeba hrát si je nejintenzivněji vnímána u malých dětí a začátku mladšího školního věku. U starších dětí prání hrát si přechází plynule do potřeby hry, kde už je cílem určitý pohybový výkon a kde jsou jasně vymezena pravidla hry. Podobně Mazal (2000) pod pojmem hraní chápe záměrnou pohybovou aktivitu jednoho i více lidí, v prostoru a čase, bez složitých pravidel, vymezených obsahem pohybové aktivity. Jsou charakterizována vysokou motivací k činnosti, napětím a uplatněním známých dovedností. V průběhu hraní se dá soutěžit i spolupracovat. Hraní je velmi široký pojem, má velmi blízko ke kreativnímu přístupu a kooperačním aktivitám. Je naší snahou vytvářet takové podmínky a vybírat hry, které budou jak zdrojem zábavy, tak prožitkem z výkonu.

\section{Gymnastické hry}

Prostřednictvím gymnastických her zlepšujeme a upevňujeme známé, v procesu pohybového učení již osvojené dovednosti. Zejména jsou-li ve hře použivány nějaké pomůcky, např. náčiní jako míče, švihadla nebo nářadí lavičky, bradla apod., je nezbytná jistá dovednostní úroveň jejich ovládání. Poněkud odlišný přístup má Perič (2012), který kategorizuje hry užívané v tréninku do čtyř tematických skupin. Jednou skupinou jsou hry tzv. dovednostní, jejichž cílem je jak nácvik nových dovedností, tak aplikace již naučených dovedností ve větších motorických celcích (sériové či paralelní dovednosti) či v proměnlivých podmínkách. Gymnastické hry je možno využít $\mathrm{v}$ kterékoli části vyučovací jednotky. Uplatnění najdou bud' v úvodu jako prostředek $\mathrm{k}$ zahřátí organizmu nebo naopak v závěru $\mathrm{k}$ jeho částečnému uklidnění. Vhodně do hry zařazené dovednosti mohou přispívat k pohybové gramotnosti, ovlivňovat vybrané složky tělesné zdatnosti a přispívat k motorickofunkční připravenosti cvičence (tzv. akrobatická příprava) potřebné k provádění dalších pohybových aktivit. Gymnastické hry výrazně přispívají k rozvoji pozornosti, vnímání prostoru, důvěry mezi cvičenci, ale také k optimální rytmizaci pohybu a k pohybové paměti.

Mazurovová a Vlasáková (1992) uvádějí, že není zanedbatelný ani př́nos gymnastických her při rozvoji morálních vlastností, jako je soudržnost s kolektivem, společná touha po vítězství, důslednost a vytrvalost při překonávání obtíží v průběhu plnění pohybových úkolů, samostatnost v rozhodování, spolupráce a ochota pomoci jeden druhému. Činnosti prováděné závodivou formou jsou přitažlivé a zvyšují zájem o pohybové aktivity. Velké množství inspirací pro obsah pohybových her nacházíme např. v publikaci Zábavná cvičení (Kos, 1992; Chrudimský et al., 2012; Novotná et al. 2011). Při osvojování gymnastických dovedností nelze jednoznačně vymezit poměr formy hry vzhledem k „drilovému“ způsobu nácviku. Volba přístupu se odvíjí především od věku cvičenců, jejich úrovně tělesné zdatnosti, míry zvládnutých dovedností, očekávaného typu výkonu a podmínek prostředí.

Pro tvorbu gymnastických her je východiskem komplexní vzdělávací systém realizovaný prostřednictvím komise Gymnastiky pro všechny (GFA). Propracovaný gymnastický program je doporučován trenérům, cvičitelům, instruktorům sportovních organizací i učitelům tělesné výchovy zabývajícím se gymnastickými aktivitami. Je v něm naplňována myšlenka, že není důležitý výkon, ale že gymnastika je vhodná pro každého, bez ohledu na věk, pohlaví a výkonnost (Ahlquist, Russell \& Fink, 2010). Základní filosofie GFA pro všechny

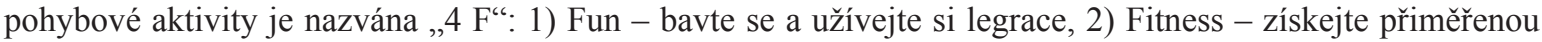
tělesnou zdatnost, 3) Fundamentals - osvojte si dobré pohybové základy, 4) Friendship - užívejte si přátelské vztahy a vytvářejte nová přátelství.

\section{Inovace ve školní tělesné výchově}

Do prostředí pro výuku tělesné výchovy je nezbytné integrovat moderní technologie a inovovat př́stupy k výuce pohybových aktivit. Značná část výuky gymnastiky, zejména cvičení s využitím nářadí, se dosud odehrává v podmínkách, které jsou učiteli i žáky považovány za nevhodné z důvodu nedostatečné kvality vybavení. V mnoha školách zůstalo pouze původní „historické“ náŕadí, se kterým se velmi špatně manipuluje, zatímco mimo školu jsou dnes zájemcům běžně dostupná sportovní centra s moderními pomůckami pro nácvik specifických dovedností. Používané nářadí je atraktivní, pro děti lákavé a inspirativní. Manipulace se všemi pomůckami je snadná a časově nenáročná. Zvyšuje se bezpečnost nácviku jednotlivých dovedností a rozšiřuje se množství impulsů pro podněcování tvořivosti. Vstřícnou atmosféru pro přijímání cvičení je možno podpořit hudbou ke cvičení. 


\section{Nácvičné náráadi}

Nové nářadí přináší gymnastickým hrám další zatraktivnění. V současné době je možné pořídit do škol i nářadí vyrobené z molitanu (pěnového polyuretanolu). Povrch je omyvatelný, různobarevný, usnadňuje provedení vybraných gymnastických prvků a zvyšuje bezpečnost nácviku gymnastických dovedností. Př́ikladem je stavebnicová souprava EducGym obsahující pěnové modely - válce, kvádry, šikmé žíněnky, kruhové výseče (malé i velké díly); dřevěné díly - žebříky, schůdky, lavičky a kladiny (díky dokonalému bezpečnostnímu systému do sebe díly perfektně zapadají); díly pro základní gymnastické dovednosti jako jsou jednoduchá akrobatická cvičení - malá trampolína, pěnový kůň, nácvičné kladiny; žíněnky - velký výběr, lehké, ohebné, snadno se s nimi manipuluje; malé vzdělávací díly či předměty - hranoly, tyče, míčky. Pro každou lekci lze postavit „,nový svět“", který si děti prožijí s nadšením.

Dalším nářadím jsou různě velké molitanové kostky, na kterých je možno provádět základní akrobacii, např. kotouly a sudy při vytvoření šikmé plochy. Mohou být použity jako překážka ke zdolávání různými způsoby lokomoce, napřs. přelézáním, vylézáním, slézáním, ale i k vyskakování a seskakování, nebo také jako prreskokové nářadí (skrčka, přemet, rondát). Lze provádět i další činnosti ve vzporu, jako je ručkování kolem nářadí nebo komíhání mezi dvěma kostkami.

Místo obávané „kozy“ nebo „koně“ je možno použít molitanovou bednu, popř. stůl. Její nespornou výhodou je snadná manipulace, možnost změny výšky nebo i změna tvaru. Stává se, že při překonávání překážek se u některých cvičenců objevují negativní pocity jako je úzkost a strach. Změkčené nářadí může tyto pocity minimalizovat. Obměnou jsou i úkolové žíněnky, které doplňují nebo nahrazují tzv. úkolové karty, na kterých je pohybový úkol graficky nebo jinak znázorněn. Jsou vhodné jak pro cvičení jednotlivců, tak i pro skupinové nebo hromadné formy výuky a pro hry.

Zcela novým nářadím, často využívaným ve školách v zahraničí, je „AirTrack“. Nafukovací akrobatickou dráhu tvoří dlouhý pás různé výšky. Kompresorem je do něj vháněn vzduch upravující „tvrdost žíněnky“. $\mathrm{Na}$ AirTracku lze snadněji formou hry (napřs. na „zvířátka“ žábu, králíka, kobylky, apod.) nacvičovat různé akrobatické dovednosti, procvičovat jednotlivé prvky akrobatické přípravy, bezpečně zdokonalovat i další gymnastické dovednosti.

\section{ZÁVĚR}

Gymnastické hry se mohou stát významným podnětem k modernizaci výuky gymnastiky ve školní tělesné výchově. Využití her mohou provázet i př́padná rizika, která je nutno předem eliminovat. Je třeba mít na paměti, že by se do hry měli zapojit všichni cvičenci a je vhodné vyhnout se takovým, kde jsou ti slabší rychle vyřazeni, nebo nedostačuje počet potřebných pomůcek. Je důležité vytvářet takové podmínky pro výuku, aby mohli být cvičenci úspěšní po většinu času své pohybové aktivity a dostávali pozitivní zpětnou vazbu.

Gymnastické hry mohou přispívat k ovlivňování celého komplexu klíčových kompetencí žáků. Je možno uvést některé konkrétní př́iklady: Kompetenci k učení posiluje zdokonalování pohybového projevu vycházejícího z potřebných znalostí o provedení pohybu a pravidlech hry. Kompetenci k řešení problémů představuje zejména cvičení s využitím nářadí, navozující různé problémové situace a provokující hledání vhodného způsobu řešení pohybového úkolu. Žáci zde dostávají př́iležitost ke spolupráci a pomoci při řešení pohybového úkolu, a také si uvědomují vzájemnou součinnost a spoluzodpovědnost za svá rozhodnutí. Komunikativní kompetence se projevuje ve skupinových hrách a soutěžích týmů, dochází k pohybové komunikaci a ke sdílenému spoluprožívání. Sociální kompetenci podporuje spolupráce při gymnastických hrách, začlenění do kolektivu a vlastní př́nos, který nemusí být vždy vyjádřen výkonem, jako např́íklad tvưrčí činnost při vzniku a prezentaci pohybové skladby. Zvládnutí společných gymnastických her přispívá k sebevědomí a sebedůvěře. K občanské kompetenci patří výchova $\mathrm{k}$ fair play, a to nejen ve sportu, ale i přenesení těchto zásad chování a jednání do všedního života. Pracovní kompetenci posiluje překonávání námahy při osvojování gymnastických cvičení zvyšujících celkovou odolnost a podporujících přípravu jednotlivce i skupiny na budoucí profesi.

V gymnastických činnostech se ovlivňování všech klíčových kompetencí vzájemně prolíná a doplňuje. Předpokládáme, že modernizace výuky gymnastiky prostřednictvím gymnastických her může ovlivnit úroveň pohybové gramotnosti, zvýšit počet osvojených dovedností, a tím se stát důležitou motivací k celoživotní pohybové aktivitě vedoucí ke zdravému životnímu stylu. 


\section{LITERATURA}

Ahlquist, S. M., Russell, K. \& Fink, H. et al. (2010) Foundation of Gymnastics. Ruschkin: Saskatoon.

Balada, J. et al. (2007). Rámcový vzdělávací program pro gymnázia. Praha: VÚP.

Belz, H. \& Siegrist, M. (2001). Kličové kompetence a jejich rozvíjení: východiska, metody, cvičení a hry. Praha: Portál.

Bučar, P. M., Čuk, I., Kovač, M. \& Jakše, B. (2010). Implementation of the Gymnastics curriculum in the third cycle of basic school in Slovenia. Science of Gymnastics Journal, 2 (3), 15-27.

Eacea. (2013). Physical Education and Sport at School in Europe. http://eacea.ec. europa.eu/education/eurydica/ thematic_studies_en.php

Chrudimský, J. (2011). Gymnastika pro všechny pomůže oživit školní tělesnou výchovu. Tělesná výchova a sport mládeže, 77 (1), 31-33.

Chrudimský, J., Krištofič, J., Marek, J., \& Vorálková, J. (2012). Gymnastika v obrazech. Multimediální učební text. Praha: UK FTVS.

Kos, B. (1992). Zábavná cvičení. Praha: Olympia.

Mazal, F. (2000). Pohybové hry a hraní. Olomouc: Hanex.

Mazurovová, Z. \& Vlasáková, N. (1992). Pohybové hry ve sportovni gymnastice. Praha: Gym Game.

Němec, J. (2004). S hrou na cestě za tvořivostí. Brno: Paido.

Neuman, J. (2007). Dobrodružné hry a cvičení v přirodě. 4. vydání. Praha: Portál.

Novotná, V., Panská, Š. \& Šimůnková, I. (2011). Rytmická gymnastika a pohybová skladba-programy cvičení s hudbou. Multimediální učební text. Praha: UK FTVS.

Olivová, V. (1979). Lidé a hry. Historická geneze sportu. Praha: Olympia.

Perič, T. (2004). Hry ve sportovní př́pravě dětí. Praha: Grada.

Perič, T. (2012). Techniques of Learning to Assist Coaching. IIHF International Youth Coaching Symposium. IIHF, Helsinky (Fi). http://www.hockeycentre.org/inEnglish/Seminars/ 2012IIHFInternational YouthCoachingSymposium/tabid/3034/language/en-US/Default.aspx (4.5.2012)

Průcha, J., Walterová, E. \& Mareš, J. (1995). Pedagogický slovník. Praha: Portál.

Rychtecký, A., Hardman, K., Klein, G., et al. (2008). Trendy v přípravě učitelů tělesné výchovy v evropském kontextu. Česká kinantropologie, 12 (1), 5-27.

Sigmund, E., Frömel, K., Chmelík, F., Lokvencová, P. \& Groffik, D. (2009). Oblíbený obsah vyučovacích jednotek tělesné výchovy - pozitivně hodnocený prostředek vyššího tělesného zatížení děvčat. Tělesná kultura, $32(2), 45-63$.

Sloan, S. (2007). An investigation into the perceived level of personal subject knowledge and competence of a group of pre-service physical education teachers towards the teaching of secondary school gymnastics. European physical educational rewiew. 13 (1), 57-80.

Živčić, M. K., Sporiš, G. \& Čavar, I. (2011). Initial state of motor skills in sports gymnastics among students at Faculty of Kinesiology. Acta kinesiologica, 5 (1), 67-72. 